\title{
Bogusz Wasik
}

\section{Zamek w Kowalewie Pomorskim - pierwsze wyniki badań archeologicznych}

Zamek w Kowalewie Pomorskim był do niedawna jedną ze słabiej rozpoznanych warowni krzyżackich ziemi chełmińskiej' ${ }^{1}$ W końcu XIX wieku krótki opis historii i pozostałości zamku przedstawił w swojej pracy Conrad Steinbrecht ${ }^{2}$. Opublikował on także rzut zamku, uwzględniający nieistniejące już wówczas jego części, sporządzony na podstawie (obecnie zaginionego) szkicu inżyniera Giese z 1820 roku. Plan ten jest nieprecyzyjny i traktować go należy z pewną ostrożnością. Wkrótce zamek opisał także Johannes Heise, nie wnosząc jednak wiele nowego ${ }^{3}$. Kolejna szersza próba rekonstrukcji zamku powstała dopiero sto lat później. Bogumił Rogalski podjął się charakterystyki zamku na szerszym tle architektury zamkowej państwa krzyżackiego. Próbując odtworzyć wygląd założenia przeanalizował nowożytne lustracje, opracował także nową rekonstruk-

1 W artykule zaprezentowano wyniki badań archeologiczno-architektonicznych z lat 2013-2014, które następnie były kontynuowane do 2016 r. i umożliwiły rekonstrukcję zespołu zamkowego. Aktualny stan badań zob.: Bogusz WasıK, Zamek, kościół i mury miejskie w Kowalewie Pomorskim - kwestia czternastowiecznych warsztatów budowlanych, „Biuletyn Historii Sztuki”, 79, 2017, nr 1, s. 71-86; Bogusz Wasik, Marcin Wiewióra, Próba rekonstrukcji układu przestrzennego zamku wysokiego (domu konwentu) w Kowalewie Pomorskim na podstawie źródeł historycznych i najnowszych wyników badań archeologiczno-architektonicznych, „Wiadomości Konserwatorskie”, 45, 2016, s. 53-65; Marcin Wiewióra, Krzysztof Misiewicz, Bogusz WasıK, Wiesław MaŁkowski, Przedzamcze zachodnie zamku w Kowalewie Pomorskim w świetle badań nieinwazyjnych $i$ archeologiczno-architektonicznych, „Wiadomości Konserwatorskie”, 51, 2017, s. 42-52.

2 Conrad Steinbrecht, Die Baukunst des Deutschen Ritterordens in Preußen, 2, Preußen zur Zeit der Landmeister, Berlin 1888, s. 26-27.

3 Johannes HeIse, Die Bau- und Kunstdenkmäler der Provinz Westpreußen, 6-7: Der Kreis Thorn, Danzig 1889, s. 186-187. 
cję rzutú. Przedstawione przez niego poglądy, wnioski z analizy lustracji i plan budzą jednak wiele wątpliwości. Poza powyższymi, opisy zamku zamieszczano w wielu pracach charakteryzujących szerzej budownictwo zamkowe w Polsce lub Prusach ${ }^{5}$, przeważnie powtarzają one jednak informacje znane ze starszych opracowań.

Nie znamy źródeł ikonograficznych ukazujących zamek. Jego ruiny widnieją jedynie w tle ryciny przedstawiającej popis wojska w $1697 \mathrm{roku}^{6}$. Ten schematyczny widok nie jest jednak pomocny przy rekonstrukcji wyglądu budowli. Opisy inwentaryzacyjne z lat $1664^{7}$ i $1765^{8}$ są natomiast mało szczegółowe. Na ich podstawie można odtworzyć ogólny układ założenia zamkowego - przedzamczy i ich zabudowy, lecz detale wyglądu, zwłaszcza zamku wysokiego, nie są na ich podstawie możliwe do rekonstrukcji.

W Kowalewie Pomorskim już przed budową murowanego zamku komturskiego istnieć musiała drewniano-ziemna warownia. Falsyfikat z Lonyz wymienia były gród, który biskup Chrystian przekazał w 1231 roku Krzyżakom. Być może wznieśli oni tam wówczas strażnicę, ale kolejne wzmianki pochodzą dopiero z lat 70. XIII wieku, kiedy warownia była oblegana przez Prusów9. Z przeprowadzonych dotąd badań wynika jednak, że obiekty te musiały znajdować się w innym miejscu niż murowany dom konwentu, gdyż ten ostatni został wzniesiony „na surowym korzeniu”. Data rozpoczęcia budowy murowanego zamku nie jest pewna. Wskazówką może być moment utworzenia komturii - jak wynika z badań Sławomira Jóźwiaka, nastąpiło to między 1272 a 1275 rokiem, a więc wkrótce po najazdach Jaćwięgów ${ }^{10}$. Mniej więcej w tym samym czasie założono miasto, które otrzymało prawa miejskie w 1298 roku ${ }^{11}$.

4 Bogumił Rogalski, Komturski gotycki zamek krzyżacki w Kowalewie na tle ówczesnej architektury obronnej zakonu, [w:] Dzieje Kowalewa Pomorskiego, red. Jerzy DaniELEwicz, Bydgoszcz 1986, s. 57-95.

5 M.in. Bohdan Guerouin, Zamki w Polsce, Warszawa 1984, s. 174; Mieczysław Haftka, Zamki krzyżackie $w$ Polsce. Szkice $z$ dziejów, Malbork-Płock 1999, s. 135-139; Leszek KaJZER, Stanisław KoŁodziejSKI, Jan SALM, Leksykon zamków w Polsce, red. Leszek Kajzer, Warszawa 2001, s. 231; Tomasz Torbus, Die Konventsburgen in Deutschordensland Preußen, München 1998, s. 137; TENŻE, Zamki konwentualne Państwa Krzyżackiego w Prusach, Gdańsk 2014, s. 154-157.

6 Widok ten opublikował Rogalski 1986, s. 91.

7 Opis królewszczyzn w województwach chelmińskim, pomorskim i malborskim w roku 1664, wyd. Józef Paczkowski, Torun 1938 (dalej cyt.: OpIS KRólewszczyzn [1938]), s. 3.

8 Lustracja województw Prus Królewskich 1765, 2, Województwo chelmińskie, cz. 2: Ziemia chelmińska, wyd. Jerzy DygdaŁa, Toruń 2009 (dalej cyt.: Lustracja województw [2009]), s. 175-176.

9 Dariusz Poliński, Późnośredniowieczne osadnictwo wiejskie w ziemi chełmińskiej, Toruń 2003, s. 182; Rogalski 1986, s. 72; ToRBus 1998, s. 637.

10 Sławomir Jóźwiak, Powstanie i rozwój struktury administracyjno-terytorialnej zakonu krzyżackiego na Kujawach i ziemi chelmińskiej w latach 1246-1343, Toruń 1997, s. 90-96.

11 SteInBREcht 1888, s. 26. 
Po przejściu w wyniku wojny trzynastoletniej w ręce polskie, zamek stał się siedzibą starostów. Warownia znacznie ucierpiała podczas potopu szwedzkiego i nie została podźwignięta w pełni ze zniszczeń aż do rozbiorów. W połowie XIX wieku ruiny zamku zostały rozebrane, a na terenie przedzamcza środkowego wybudowano kościół ewangelicki ${ }^{12}$.

Zamek komturski był sprzężony z murami miasta i rozciągał się wzdłuż całego jego zachodniego boku. Od północy zespół ten ograniczało wyschnięte obecnie jezioro. Obiekt składał się z kilku członów (il. 1). Na wzniesieniu nad brzegiem jeziora mieścił się dom konwentu otoczony parchamem łączącym się z przedzamczem zachodnim. W murach tego ostatniego usytuowana była baszta. Na południe od zamku wysokiego i przedzamcza zachodniego znajdowały się dwa kolejne człony - przedzamcze środkowe i południowe, których, jak wynika z opisów, a wbrew temu, co narysował Conrad Steinbrecht, nie rozdzielała fo$\mathrm{sa}^{13}$. W lustracjach nowożytnych na przedzamczach wymieniana jest w zasadzie tylko zabudowa nietrwała, ale w średniowieczu wzmiankowany jest na którymś z nich (lub na parchamie) budynek („gemach”) gości zakonnych ${ }^{14}$.

$\mathrm{Z}$ całego zespołu do dziś zachowały się przede wszystkim pozostałości przedzamczy - mury (południowy, wschodni i zachodni) przedzamcza południowego wraz z basztami (il. 2) oraz baszta i relikty wschodniej kurtyny przedzamcza środkowego. Z przedzamcza zachodniego pozostał pusty plac i kilka murowanych reliktów u podnóża północno-zachodniego stoku wzniesienia (związanych raczej z murem zewnętrznym zamku). Dobrze zachował się natomiast południowo-wschodni odcinek parchamu zamku wysokiego wraz z przyległymi odcinkami fos. Szczególnej uwagi wart jest ponadto dekorowany blendami, tynkowanymi fryzami i wzorami z zendrówek filar gdaniska ${ }^{15}$ (il. 3). Nie zachowały się natomiast żadne czytelne w terenie relikty głównej części zamku - domu konwentu. Dlatego też rozpoznanie tego członu założenia stało się pierwszym celem badań archeologicznych, prowadzonych od 2013 roku $^{16}$.

$\mathrm{Z}$ powodu braku innych śladów jedynym elementem wskazującym na położenie domu konwentu jest filar gdaniska. Stał się on więc punktem oparcia dla wytyczonej w 2013 roku osi północ-południe ${ }^{17}$, wzdłuż której wyznaczono pięć

12 HaftKa 1999, s. 139.

13 LuSTRACja WojewódzTw [2009], s. 175; OpIS KRóleWSZCZyZN [1938], s. 3; STEINBREcht 1888, s. 26-27.

14 Sławomir JóźWIAK, Janusz TrupINDA, Krzyżackie zamki komturskie w Prusach. Topografia i układ przestrzenny na podstawie średniowiecznych źródeł pisanych, Toruń 2012, s. 93.

15 Bogusz WasıK, Architektura zamku w Kowalewie Pomorskim w świetle badań z 2013 roku [mps], Toruń 2013 (dostęp - Instytut Archeologii UMK w Toruniu).

16 Badania prowadzone były pod kierunkiem Marcina Wiewióry z Instytutu Archeologii UMK, przy współudziale autora niniejszego artykułu.

${ }_{17}$ W rzeczywistości oś była odchylona w kierunku północno-wschodnim, ale dla uproszczenia przyjęliśmy, iż przebiega w kierunku północ-południe. 
wykopów (nr 1-5 licząc od północy) o wymiarach 2,5 x 6 m, przy czym wykop południowy (nr 5) został przesunięty w stosunku do pozostałych na zachód ze względu na obecność w pobliżu słupa wysokiego napięcia. Podczas eksploracji wykopy 1-3 połączono, a wykop 5 został poszerzony. Ponadto wytyczone zostały dwa wykopy ( $2 \times 5 \mathrm{~m}$ ) na osi prostopadłej do powyższych, po ich zachodniej stronie (wykopy nr 6 i 7). Natomiast w 2014 roku założono dwa kolejne wykopy (nr 8 i 9 o wymiarach 2,5 x 6 m; później połączone) przedłużające w kierunku południowym cięcie góry na osi północ-południe (przez parcham), dwa wykopy w rejonie skrzydła południowego ( $\mathrm{nr} 10-2$ x 6 m i $12-4$ x 8,5 m) oraz jeden (nr 11 - 4 x $6 \mathrm{~m}$ ) w przestrzeni między wykopami 6 i 7 z poprzedniego sezonu (il. 1). Podczas obu sezonów wykonano serie odwiertów przecinających przedzamcze środkowe, zachodnie i stok północny wzgórza.

Wykopy badawcze spełniły swoje zadanie. Na osi północ-południe przecięty został teren całego domu konwentu i południowy parcham. Rozpoznane zostało dzięki temu jego położenie i rozpiętość. W wyniku badań udało się także ustalić zachodni zasięg zamku wysokiego wraz z przybliżonym wymiarem znajdującego się $\mathrm{z}$ tej strony skrzydła.

Podczas badań okazało się, że budynek zamku wysokiego został w XIX wie$\mathrm{ku}$ gruntownie rozebrany włącznie z fundamentami tak, że jedynie w niektórych miejscach zachowały się bardzo skromne murowane relikty. Przetrwały natomiast w dużym stopniu bruki dziedzińca oraz piwnic. Stało się tak najprawdopodobniej dlatego, iż podczas XIX-wiecznej rozbiórki były one już przykryte gruzem. Mimo znacznego stopnia destrukcji, sposób w jaki zamek popadał w ruinę, umożliwia rekonstrukcję przebiegu murów na podstawie negatywów porozbiórkowych. Od „potopu szwedzkiego” stan techniczny budowli pogarszał się. Przez cały wiek XVIII dom konwentu powoli ulegał zniszczeniu w taki sposób, że piwnice wypełniły się w pierwszej kolejności gruzem ze spadających sklepień i konstrukcji dachu. W XIX wieku przeprowadzono gruntowną rozbiórkę stojących jeszcze ścian, przez co powstały głębokie, wypełnione gruzem rowy porozbiórkowe. Od południa są one szersze niż pierwotna grubość kurtyny południowej domu konwentu, ale dzięki ocalałemu zasięgowi głębiej zalegających warstw można oszacować grubość nieistniejącego muru. Ponadto na położenie ścian wskazują także zasięgi ocalałych bruków wnętrz piwnic.

W centralnie położonych wykopach ( $\mathrm{nr} 3$, 4, oraz świadek 2/3) udało się odsłonić dziedziniec domu konwentu (il. 4). W jego północnej połowie dobrze zachował się bruk z kamieni polnych, zalegający około $0,5 \mathrm{~m}$ pod obecnym poziomem gruntu (ok. 99 m n.p.m.). W części południowej został on zniszczony w wyniku ścięcia górnych nawarstwień podczas porządkowania i plantowania wzgórza w XIX wieku. Rozpiętość dziedzińca na osi północ-południe można szacować na około $18 \mathrm{~m}^{18}$.

18 Agata Момот, Bogusz WAsıK, Badania archeologiczno-architektoniczne zamku krzyżackiego w Kowalewie Pomorskim w 2013 roku [mps], Torun 2013 (dostęp: Instytut Archeologii UMK w Toruniu). 
Nawarstwienia i relikty związane ze skrzydłem północnym zostały przecięte wykopami nr 1-2 i świadkiem 2/3. Udało się stwierdzić, że w eksplorowanym miejscu skrzydło było podpiwniczone, lecz próba osiągnięcia poziomu posadzki piwnicznej nie powiodła się ${ }^{19}$. Na profilach czytelne były natomiast negatywy po rozebranych ścianach skrzydła. Ponadto w zasypisku kurtyny północnej domu konwentu odsłonięto kamienny ostaniec łączony zaprawą. Na podstawie tych śladów szerokość tego, jak i dalszych skrzydeł, można szacować na około 12,5-13 m²0. Szczególnie interesujący relikt murowany związany ze skrzydłem północnym odsłonięty został po jego południowej stronie. Przetrwały tam pozostałości szyi ze schodami prowadzącymi z dziedzińca do wnętrza piwnicy (il. 5). Pierwotne stopnie zasadniczo się nie zachowały, przetrwał natomiast ich fundament z cegieł łączonych gliną. Na poziomie dziedzińca czytelne było ponadto położenie progu wejściowego (rząd eratyków) ${ }^{21}$.

Ślady związane ze skrzydłem zachodnim eksplorowano w trzech wykopach (nr 6, 7, 11). Również tam stwierdzono obecność piwnicy wypełnionej zasypiskiem z cegieł sklepiennych, konstrukcyjnych i dachówek. Na znacznej głębokości (3,3 m poniżej obecnego poziomu gruntu; około 96,3 m n.p.m.) udało się osiągnąć zachowaną brukowaną nawierzchnię piwnicy. Kurtyna zachodnia domu konwentu w badanym miejscu nie zachowała się, ale jej położenie można określić śledząc przebieg warstw zasypiskowych i zasięg brukowanego pomieszczenia. Ściana wschodnia natomiast znalazła się na tej wysokości poza rejonem eksploracji, ale jej położenie można zrekonstruować, gdyż najprawdopodobniej przebiegała ona na przedłużeniu odkrytej ściany działowej skrzydła południowego (o której dalej)22.

Zasięg skrzydła południowego był badany w pięciu wykopach (nr 4, 5, 8, 10, 12). Udało się ustalić linie przebiegu południowej kurtyny domu konwentu, przybliżoną szerokość skrzydła i jego zasięg w kierunku zachodnim. Ta ostatnia informacja, wraz z wynikiem opisanej wyżej eksploracji skrzydła zachodniego, umożliwiła określenie zasięgu budynku zamku wysokiego od tej strony. Co istotne, w wykopie nr 5 udało się odkryć zachowany relikt (północne lico) kamiennego fundamentu południowej ściany zamku. Odcinek kamieni licowych zarejestrowano także w wykopie nr 10. W innych miejscach odnotowano

19 Eksploracja została przerwana ze względu na zagrożenie, jakie stwarzały wysokie, usypane $\mathrm{z}$ gruzu profile wykopu.

${ }^{20}$ Wymiary zamku i skrzydeł określane są przede wszystkim na podstawie negatywów porozbiórkowych, dlatego należy je traktować jako przybliżone.

21 Момот / WasIK 2013; WasIK 2013.

22 Момот / WasiK 2013; Bogusz WasIK, Opisy wykopów badawczych [mps], Toruń 2014 (dostęp - Instytut Archeologii UMK w Toruniu, dalej cyt.: WASIK 2014c); TENŻE, Relikty architektury odkryte podczas badań archeologiczno-architektonicznych na zamku w Kowalewie Pomorskim prowadzonych w 2014 roku i wstępna analiza źródeł z nią związanych [mps], Toruń 2014 (dostęp - Instytut Archeologii UMK w Toruniu, dalej cyt.: WasIK 2014d). 
jedynie szeroki, zasypany gruzem rów rozbiórkowy. W żadnym miejscu nie udało się odkryć reliktów południowego lica muru. Na podstawie maksymalnego zachowanego zasięgu nawarstwień dochodzących do rozebranego muru można jednak stwierdzić, że miał on nie więcej niż około $3 \mathrm{~m}$ grubości ${ }^{23}$. Sytuacja stratygraficzna w północnej części skrzydła (wykop nr 4) nie jest jeszcze jasna $^{24}$, ale czytelny jest zasięg negatywu po rozebranym skrzydle.

W 2013 roku udało się ponadto odkryć zachowany wyjątkowo dobrze - jak na warunki badanego obiektu - odcinek kamienno-ceglanej ściany działowej skrzydła ${ }^{25}$ (il. 6). Jej przedłużenie w kierunku północnym wyznaczało najprawdopodobniej przebieg wschodniej ściany skrzydła zachodniego ${ }^{26}$. Stwierdzono, że skrzydło południowe nie było podpiwniczone na całej długości, ale na jego krańcu zachodnim oraz w części wschodniej. W tym drugim rejonie założono wykop nr 12, w którym osiągnięto poziom bruku piwnicznego (około 1,7 m pod powierzchnią; 96,9 m n.p.m.). Natomiast w części środkowej, ograniczonej od zachodu wspomnianą ścianą działową, była przestrzeń niepodpiwniczona ${ }^{27}$.

Na podstawie badań przeprowadzonych w latach 2013-2014 można określić położenie skrzydeł północnego, zachodniego i południowego (il. 1). Dom konwentu był budowlą czteroskrzydłową z wewnętrznym dziedzińcem. Brak śladów murowanego krużganka pozwala przypuszczać, że wykonano go z drewna. Rozpiętość całej budowli na osi północ-południe można określić na około 44-45 m. Taras parchamu południowego miał natomiast około $11 \mathrm{~m}$ szerokości. Na tej podstawie stwierdzić należy, że położenie domu konwentu na planie rekonstrukcyjnym Bogumiła Rogalskiego jest błędne - wysunięty jest za daleko na północ. Ponadto odrzucić trzeba jego sugestię, jakoby wieża ciśnień z początku XX wieku została wzniesiona na fundamentach narożnej wieży głównej zamku ${ }^{28}$. Wiadomo ponadto, że skrzydła były zasadniczo podpiwniczone. Jedynie, jak wspomniano, w środkowej części skrzydła południowego znajdowała się niepodpiwniczona przestrzeń.

Dotychczasowe badania tak skromnie zachowanego obiektu dostarczyły także wielu informacji odnośnie do techniki jego budowy, jakości warsztatu budowlanego i klasy architektury. Ze względu na daleko idącą destrukcję nie-

23 WASIK 2014c; WasIK $2014 \mathrm{~d}$.

${ }^{24} \mathrm{~W}$ wykopie $\mathrm{nr} 4$ stwierdzono obecność wkopu w obrębie negatywu skrzydła. Sytuacja ta nie jest obecnie wyjaśniona. Nie wydaje się, aby to był negatyw ściany. Być może wykop ten był związany z innymi, późniejszymi działaniami.

25 WASIK 2013.

26 Przekonuje do tego także fakt, że na linii wykopów przecinających skrzydło zachodnie, w których nie odkryto miejsca lokalizacji ściany wschodniej, pas ziemi na przedłużeniu owej ściany działowej jest jedyną dotąd niebadaną przestrzenią.

27 МомOT / WasiK 2013; WASIK 2013; WASIK 2014c; WasIK $2014 \mathrm{~d}$.

28 Rogalski 1986, s. 84. W rzeczywistości wieża ciśnień stoi na dziedzińcu dawnego domu konwentu - w pobliżu jego południowo-wschodniego narożnika. 
wiele można powiedzieć na temat techniki murarskiej domu konwentu. Można jedynie stwierdzić, że ściany wzniesiono z cegły na kamiennych fundamentach. Dzięki odkryciu bardzo dobrze zachowanego dalszego ciągu muru parchamu południowego ${ }^{29}$ wnioskujemy natomiast znacznie więcej o jego sposobie budowy (il. 7). Fundament wykonano z eratyków w rowie wąskoprzestrzennym (założonym w obrębie rowu wykopanego pod fosę - por. dalej). Odkrytą partię fundamentu łączono skąpo zaprawą wapienną. Na tak wymurowanym fundamencie, na poziomie gruntu z czasu budowy, wykonana została staranna warstwa wyrównawcza z cegieł ułożonych główkami. Wyższą partię kamiennego muru postawiono w wątku warstwowym. Przestrzeń między większymi kamieniami wypełniano fragmentami cegieł, całymi cegłami oraz dużą ilością fragmentów dachówek mnich-mniszka. Około 0,3 m nad opisaną warstwą wyrównawczą z cegieł wykonano warstwę z dachówek. Lico muru starannie wyrównano. Wyższa, rozebrana jego część, wykonana była z cegły (zachowały się relikty warstwy wyrównawczej). Mur ten wzniesiono z rusztowań jednosztandarowych, po których zachowały się otwory maculcowe z odciśniętymi negatywami okrągłych belek. Ponadto podczas murowania na ówczesnym poziomie gruntu wzdłuż lica odłożyła się warstwa zaprawy.

Szczególnie interesująca, jeśli chodzi o technikę budowy, okazała się analiza układu nawarstwień (il. 8). Teren zamku został w znacznym stopniu zmieniony w wyniku prac ziemnych - nasypowych i niwelacyjnych. Pierwotny poziom gruntu (warstwę próchniczą sprzed rozpoczęcia budowy zamku) odkryto około 1,1 m pod poziomem bruku dziedzińca (około 98,5 m n.p.m.). Warstwa ta opadała łagodnie w kierunku południowym, co wskazuje na to, że pierwotnie stok wzniesienia zaczynał się znacznie dalej na południe niż obecnie i był łagodniejszy. Tak więc $w$ celu podniesienia i wyrównania poziomu dziedzińca budowniczowie nanieśli tam nieco ponad metr piasku ${ }^{30}$.

Jeszcze większy i bardziej skomplikowany przebieg prac ziemnych można zaobserwować na parchamie południowym. Analiza charakteru warstw wskazuje też na problemy z jakimi zmagali się budowniczowie. Ich przyczyną był charakter geologiczny calca - gruntu, na którym został posadowiony obiekt. Jest to bardzo lekki, pylasty piasek, poprzecinany miejscami poziomymi nawarstwieniami żwirków - a zatem grunt bardzo niestabilny. Zaznaczyć należy tu wyjątkowość takiego posadowienia, gdyż zazwyczaj pod budowę wybierano grunty trwałe - najchętniej gliny. Niedogodne warunki wymusiły na budowniczych nietypowe rozwiązania. Budując na stabilnym, gliniastym podłożu

29 Północne lico południowego muru parchamu odsłonięto w wykopie nr 9. Nie udało się osiągnąć stopy jego fundamentu, ale mimo to odsłonięto mur o wysokości $3 \mathrm{~m}$ wraz ze znaczną partią fundamentu.

30 WASIK 2013. 
(np. w Papowie Biskupim, Radzyniu Chełmińskim, Wąbrzeźnie) kopano najczęściej rowy wąskoprzestrzenne o stromych profilach ${ }^{31}$. W Kowalewie natomiast pod fosę oddzielającą zamek wysoki od przedzamcza środkowego konieczne było wykonanie bardzo szerokiego przekopu - $w$ badanym miejscu (północny brzeg) o $4 \mathrm{~m}$ szerszego od zamierzonego zasięgu fosy. Ze względu na niestabilność podłoża, stok tego rowu wykonano schodkowo. Również pod południową ścianę domu konwentu wykopano szerokoprzestrzenny rów (dwukrotnie szerszy od ściany). Na dnie szerokiego rowu fosy wykonano natomiast wąskoprzestrzenny wykop fundamentowy pod opisany wyżej mur parchamu. Po wzniesieniu tego muru oraz ściany domu konwentu przystąpiono do zasypywania szerokich rowów, w efekcie czego podnoszono i wyrównywano poziom parchamu. Ponieważ warstwy przy obu murach nie stykają się, nie można na podstawie stratygrafii określić kolejności wznoszenia tych ścian. Opierając się na wynikach badań innych zamków komturskich, takich jak Radzyń Chełmiński czy Świecie, można jednak przypuszczać, że budowę rozpoczęto od wznoszenia domu konwentu, a w dalszej kolejności wykonano mur parchamu ${ }^{32}$. Poziom terenu podnoszono sypiąc sukcesywnie kilka warstw piasku (bardziej zwartego od calcowego). Wszystkich tych poziomów nie naniesiono jednak po całkowitym wzniesieniu sąsiednich murów. Obecność rozdzielających niektóre z nich nawarstwień budowlanych, złożonych z zaprawy wapiennej i drobnego gruzu, wskazuje na to, że kolejne prace ziemne wykonywane były wraz z sukcesywnym murowaniem wyższych partii ścian. Ostatecznie naniesiono około 2,5 m piasku, przysypując niemal całkowicie kamienną partię lica muru parchamu i wyrównując taras międzymurza ${ }^{33}$. Pomijając specyfikę wynikającą w tym przypadku z jakości podłoża, należy stwierdzić, że w świetle nowszych badań prace ziemne (nasypowe), prowadzone tu $z$ wielkim rozmachem, były typowe dla kasztelowych zamków komturskich wznoszonych przynajmniej do połowy XIV wieku ${ }^{34}$. Plasuje to więc pod tym względem zamek w Kowalewie Pomorskim wśród takich obiektów jak Papowo Biskupie, Golub i Radzyń Chełmiński35.

Na wysokiej klasy architekturę niemal doszczętnie rozebranego domu konwentu wskazuje natomiast wyjątkowo liczny asortyment bardzo dobrej jakości kształtek

31 Bogusz WasıK, Budownictwo zamkowe na ziemi chelmińskiej (od XIII do XV wieku), Toruń 2016, s. 67-68.

32 Bogusz WasıK, Zamek w Radzyniu Chelmińskim. Technika i etapy budowy siedziby krzyżackich komturów i konwentu, „Ochrona Zabytków”, 68, 2015, z. 1, s. 172; TENŻE, Zamek w Świeciu. Topografia i technika budowy zamku krzyżackiego, „Komunikaty Mazursko-Warmińskie”, 2 (300), 2018 (w druku).

33 Wasik 2016, s. 103-105.

34 Stan badań nad obiektami późnymi, takimi jak zamek w Ornecie, Insterburgu czy Ragnecie jest zbyt ograniczony, aby móc wyciągać dalej idące wnioski na temat zakresu prowadzonych przy nich prac nasypowych. Wydaje się jednak, że były one bardziej ograniczone, niż na zamkach z 1. poł. XIV w.

35 WasiK 2014c, s. 137-164. 
ceglanych (podczas dwóch sezonów badawczych wydzielono około 40 typów; il. 9). Niektóre z nich (żebrowe i ościeżnicowe) noszą ślady niebieskiej farby lub pobiały. Odkryto także kilka ułamków glazurowanej na zielono ceramiki budowlanej ${ }^{36}$.

Pewnej podpowiedzi, co do wyglądu elewacji domu konwentu, może dostarczyć analiza zachowanego filaru gdaniska (il. 3). Jest on zdobiony blendami, tynkowanymi pasami fryzowymi i wzorami wykonanymi z zendrówek. Mając na uwadze wspomniane bogactwo form kształtek pozyskanych z zasypiska domu konwentu można zaryzykować stwierdzenie, iż skoro tak kunsztownie wykończono podporę ustępu zamkowego, to także elewacje głównego gmachu artykułowały ostrołukowe blendy. Jest to tym bardziej prawdopodobne, iż także sąsiedni kościół farny ma ściany rozczłonkowane blendami, w których (a także w portalach) wykorzystano kształtki o analogicznych formach do tych odkrytych na zamku ${ }^{37}$. Hipotezy tej jednak nie da się bezspornie udowodnić z powodu braku odpowiednich źródeł ikonograficznych obiektu. Poza blendami, ściany zamku zdobiły także wzory z zendrówek, na co wskazuje duża ilość tego typu cegieł w gruzie porozbiórkowym.

Na podstawie dotychczasowych badań można wyciągnąć dalsze wnioski odnośnie do warsztatu budowlanego wznoszącego założenie kowalewskie. Wiele przesłanek wskazuje na to, iż przy budowie murów miejskich, kościoła farnego i zamku pracowali ci sami rzemieślnicy. Po pierwsze, cegły stosowane przy wznoszeniu kościoła i zamku mają zbieżne wymiary (80-90 x 130-150 x 300-320 mm) co przemawia za korzystaniem z jednej cegielni. Po drugie, za wspólnym warsztatem przemawia zastosowanie w kościele i w zamku analogicznych form kształtek, a także podobnego systemu zdobniczego w postaci artykulacji blendami elewacji kościoła i filaru gdaniska. Zwrócić należy jeszcze uwagę na typ wątku kamiennego zastosowanego w zachowanym murze przedzamcza i wieży narożnej murów miejskich (il. 10). Jest to wyjątkowo rzadka odmiana układu warstwowego z warstwami wyrównawczymi z całych cegieł ${ }^{38}$ położonymi główkami na płask lub w rolkę. Za tym, że cały zespół zamkowo-miejski wznoszono mniej więcej jednocześnie, przemawia także jego zwarte rozplanowanie.

Na koniec powrócić jeszcze należy do kwestii datowania budowy zamku. Cechy detalu, a także zbieżności warsztatowe z kościołem farnym ${ }^{39}$ oraz datowanie cera-

36 WasiK 2013; WasIK 2014d.

37 Z tą zasadniczą różnicą, że bogactwo ilościowe detalu z zamku znacznie przewyższa liczbę form zastosowanych w kościele.

38 Standardowo w murach kamiennych wznoszonych w wątku warstwowym na ziemi chełmińskiej wykorzystywano jedynie potłuczone cegły i gruz ceglany. Wykorzystanie całych cegieł można zaobserwować jeszcze tylko na jednym zamku z ziemi chełmińskiej - w wieży bramnej zamku bierzgłowskiego, która jest datowana na początek XIV w. (zob. ToRBus 1998, s. 77).

39 Nie ma bezpośrednich przekazów źródłowych wskazujących na czas budowy kościoła, lecz datuje się ją generalnie na 1. ćw. lub 1. poł. XIV w. Johannes Heise, na podstawie ogólnych przesłanek, datuje budowę kościoła na okres między 1286-1330, z naciskiem na pierwsze dziesięciolecia XIV w. 
miki z nawarstwień związanych z budową, wskazują, że zasadnicze prace murarskie toczyły się od przełomu XIII-XIV wieku i w ciągu pierwszej ćwierci XIV wieku ${ }^{40}$.

Podczas badań pozyskano liczny materiał źródłowy, którego analiza umożliwi przybliżenie życia codziennego mieszkańców zamku komturskiego i starościńskiego. Są to przede wszystkim duże ilości fragmentów ceramiki naczyniowej z różnych okresów, odpadki pokonsumpcyjne, ale także monety średniowieczne i nowożytne. Na wyposażenie wnętrz z czasów nowożytnych składają się natomiast fragmenty kafli piecowych. Na szczególną uwagę zasługują ponadto przedmioty kościane, w tym pionki do gry, odkryte po zachodniej, zewnętrznej stronie domu konwentu.

Podsumowując dwa pierwsze sezony badań archeologicznych na zamku w Kowalewie Pomorskim należy stwierdzić, iż mimo znacznego stopnia destrukcji budowli, wyniki badań są bardzo zachęcające i wnoszą wiele nowej wiedzy na temat tego słabo dotąd znanego obiektu. Nasunęły one także między innymi pytania, dlaczego krzyżaccy inwestorzy i budowniczowie zdecydowali się na wzniesienie warowni akurat w tym miejscu, mimo niekorzystnych warunków dla posadowienia budowli. Skądinąd wiadomo, że architekt miał duży wpływ na dobór miejsca pod budowę ${ }^{41}$. Może to wskazywać na wyraźną wolę inwestora.

W kolejnych sezonach konieczne będzie dokończenie badań domu konwentu, przede wszystkim rozpoznanie dotąd nieeksplorowanego skrzydła wschodniego. W dalszej kolejności planowane jest przebadanie przedzamczy, zwłaszcza środkowego i zachodniego.

\section{Bogusz Wasik}

The Institute of Archeology, Nicolaus Copernicus University in Toruń

\section{The Castle in Kowalewo Pomorskie - initial results of archaeological studies}

Until recently the state of knowledge about the castle in Kowalewo Pomorskie was very limited. This was partly due to the poor level of preservation of the castle (only

(zob. HeIsE 1889, s. 189). Początek XIV w. jako czas pierwszego etapu budowy kościoła przyjęto także w Katalogu Zabytków Sztuki w Polsce, zob. Tadeusz CHrzanowskI, Marian KorneckI, Powiat golubsko-dobrzyński, („Katalog Zabytków Sztuki w Polsce” 9/6), Warszawa 1973, s. 21. Christofer Herrmann przesuwa natomiast czas budowy kościoła na 2. ćw. XIV w. (zob. Christofer HerRmanN, Mittelalterliche Architektur im Preußenland. Untersuchungen zur Frage der Kunstlandschaft und Geographie, Petersberg-Olsztyn 2007, s. 716).

40 Wskazówką do datowania budowy może być też nadanie praw miejskich w 1298 r. (STEINBRECHT 1888, s. 26).

41 Marian Arszyński, Budownictwo warowne zakonu krzyżackiego w Prusach (1230-1454), Torun 1995, s. 155-157. 
fragments of the walls of the outer castle survive) and partly because of the limited amount of written sources (only a few lacklustre records from early-modern visitations) and near lack of iconographic sources concerning the castle. The reconstruction of the plan of the castle was based mostly on a sketchy plan which was based on yet another image made in the end of the $19^{\text {th }}$ century by Conrad Steinbrecht. Because no part of the house of the convent has remained standing, this section of the castle was the first to be studied archaeologically. The archeological analysis of this section of the castle began in 2013 (two seasons of excavation), and was led by Marcin Wiewióra from the Institute of Archeology of the Nicolaus Copernicus University in Torun. The author of this text also participated in the study.

Historical sources imply that in 1231 an abandoned stronghold was located on the site which was taken into possession by the Teutonic Order from bishop Chrystian, and presumably rebuilt. However, archeological examination suggests that the older keep had to be located in a different place than the stone castle. Trenches intersecting on the north-south axis and, partially, east-west axis revealed layers connected to the castle and allowed for the identification of its location and size. It was also discovered that during the demolition of the castle in the $19^{\text {th }}$ century the walls of the castle were almost entirely destroyed.

During the archeological studies carried out in 2013 and 2014 it was established that the castle's convent had regular shape with four wings and measured around 42-44 meters along its north-south axis. The north and west wings of the convent had cellars and were around 12 and 13 meters wide respectively. Most of the southern wing also had cellars, apart from the centre section, and was around 13,5 meters wide. Construction methods used during the building of the castle were also discovered - the mason works were accompanied by extensive earthworks which led to the courtyard being raised by about 1 meter and leveled-out. The inter-wall (parcham) area was filled with around 2.5 meters of sand. A lot of movable material was also discovered during the excavation, including a large variety of ceramic architectural detail.

In light of the results of the conducted archeological studies it is likely that the construction of the brick castle was carried out by the same workshop which worked on the construction of the city walls and the parish church. There is numerous evidence that suggests this, including the similar form of the fittings and the size of the bricks, as well as the similarity of the methods of construction and in terms of the style. This means that the initial work on the castle can be dated to the end of the $13^{\text {th }}$ century and the beginning and first half of the $14^{\text {th }}$ century. Study on this site is still in progress. 


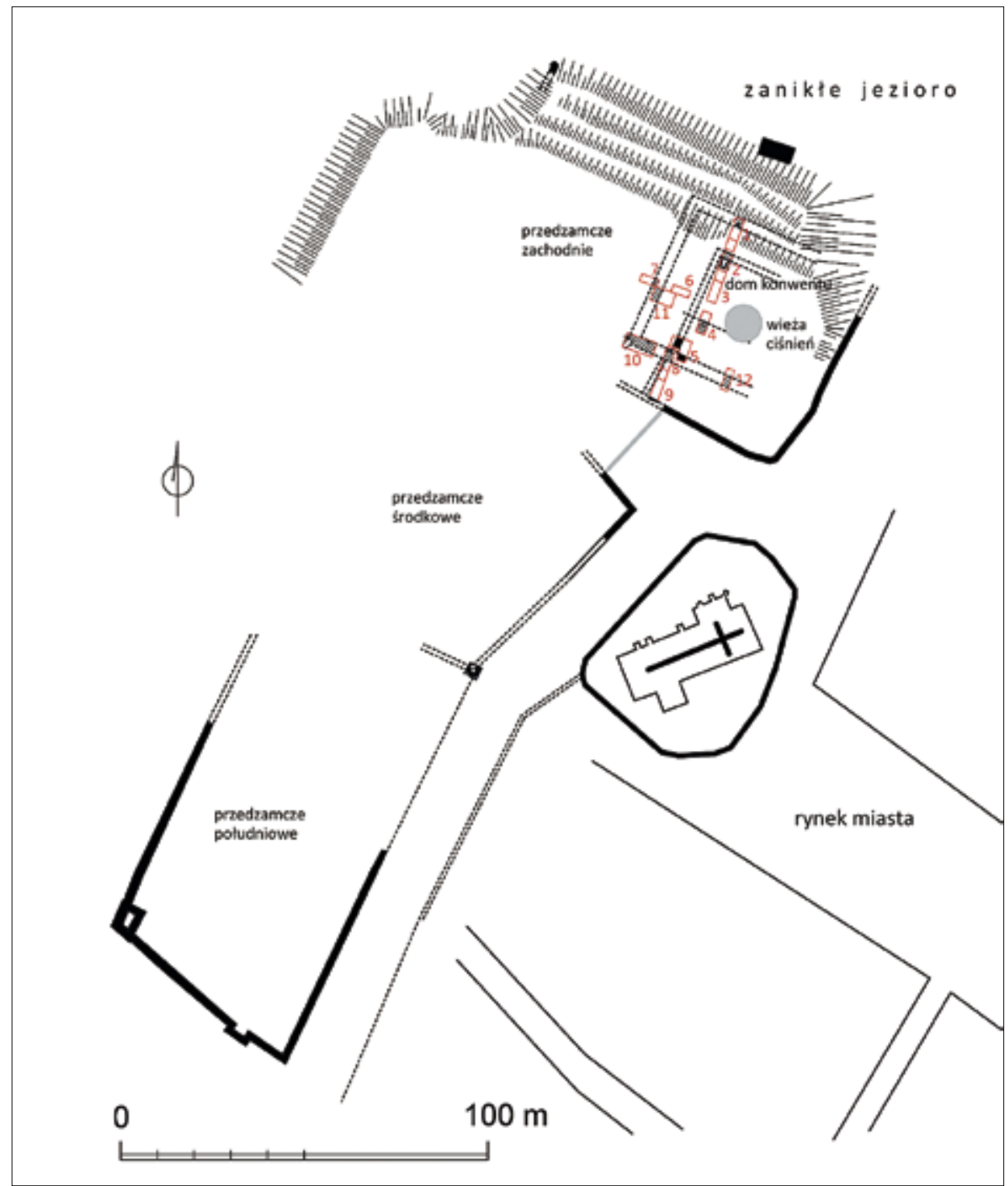

Il. 1. Kowalewo Pomorskie, rzut pozostałości zamku i wykopów badawczych z 2013 i 2014 roku. Oprac. B. Wasik 


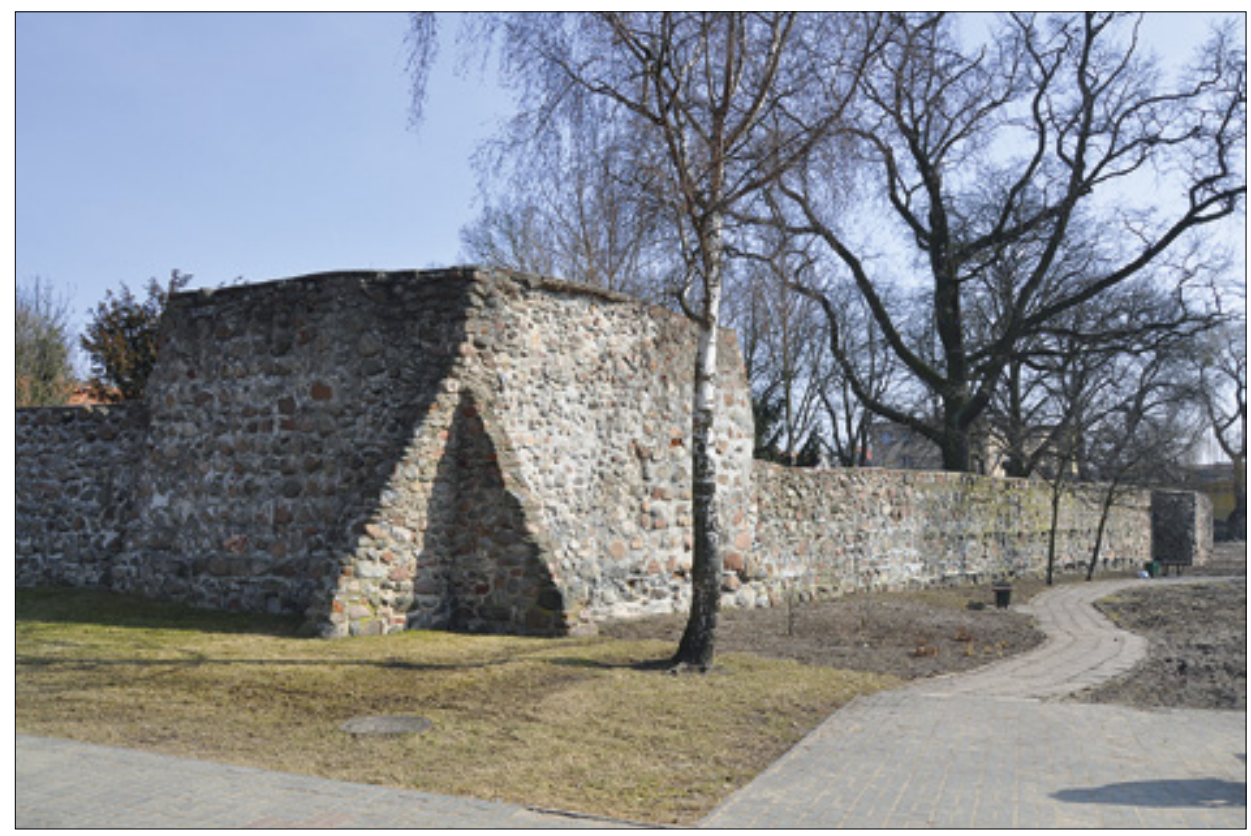

Il. 2. Kowalewo PomorskiE, zachowane mury i baszty południowego przedzamcza. Fot. B. Wasik

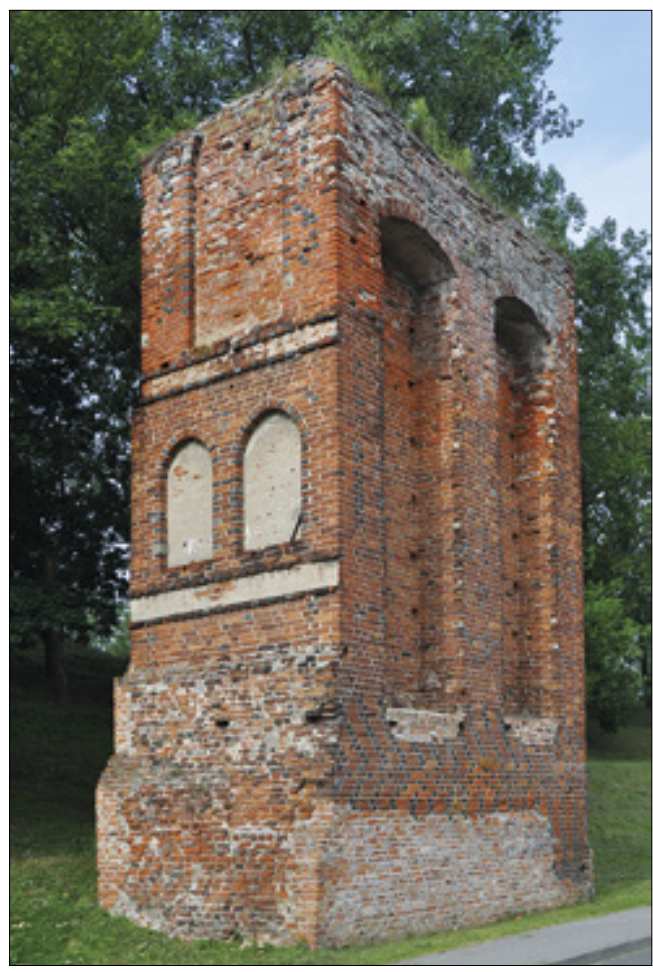

Il. 3. Kowalewo Pomorskie, filar gdaniska. Fot. B. Wasik 


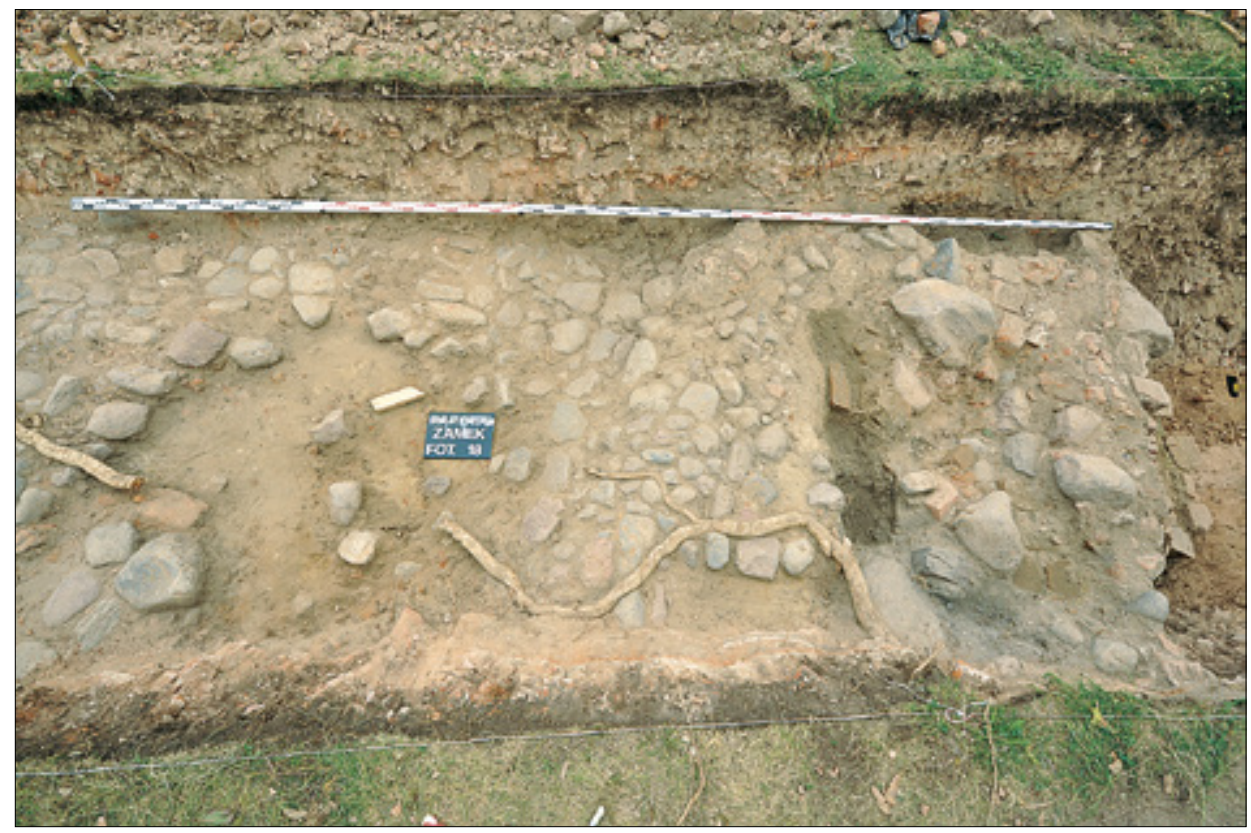

Il. 4. Kowalewo PomorskiE, wykopy nr 2-3, bruk dziedzińca domu konwentu. Fot. B. Wasik

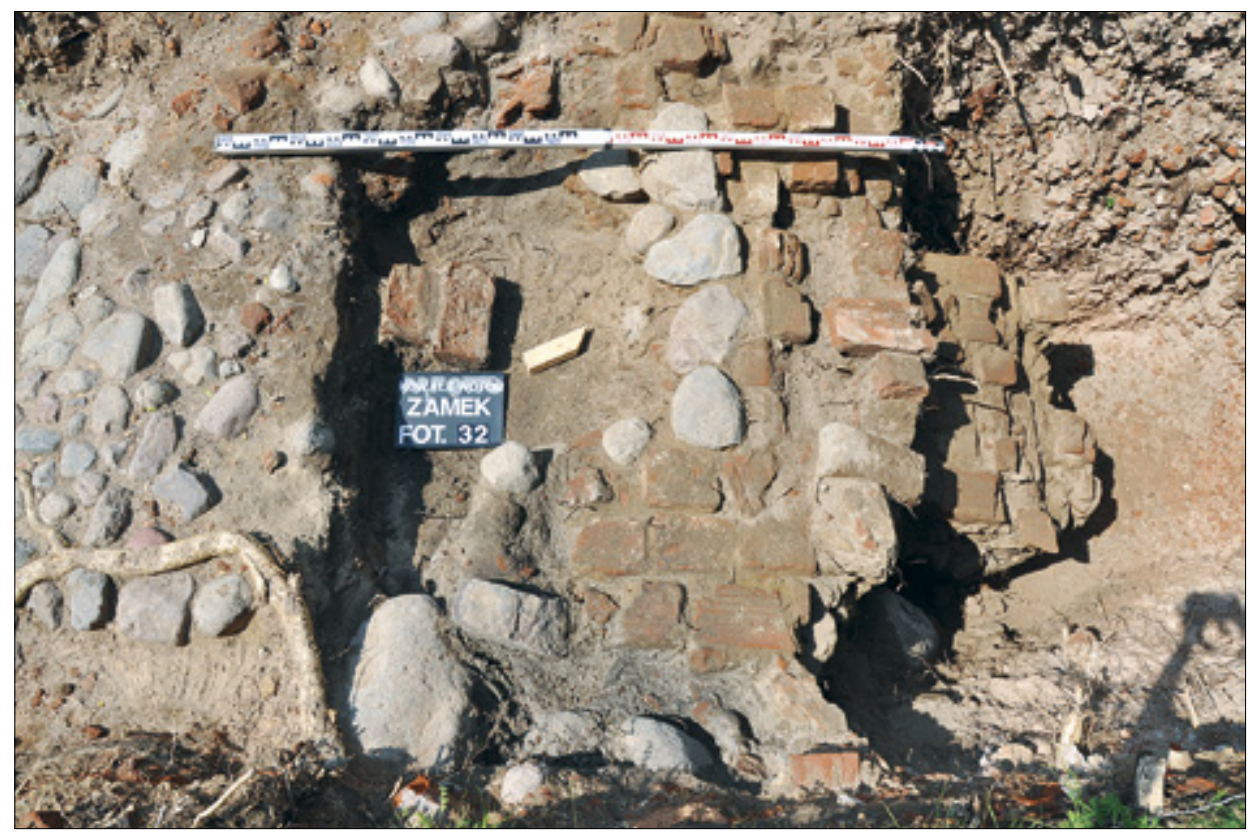

Il. 5. Kowalewo PomorskiE, wykop nr 2, relikty szyi ze schodami prowadzącymi do piwnicy skrzydła północnego. Fot. B. Wasik 


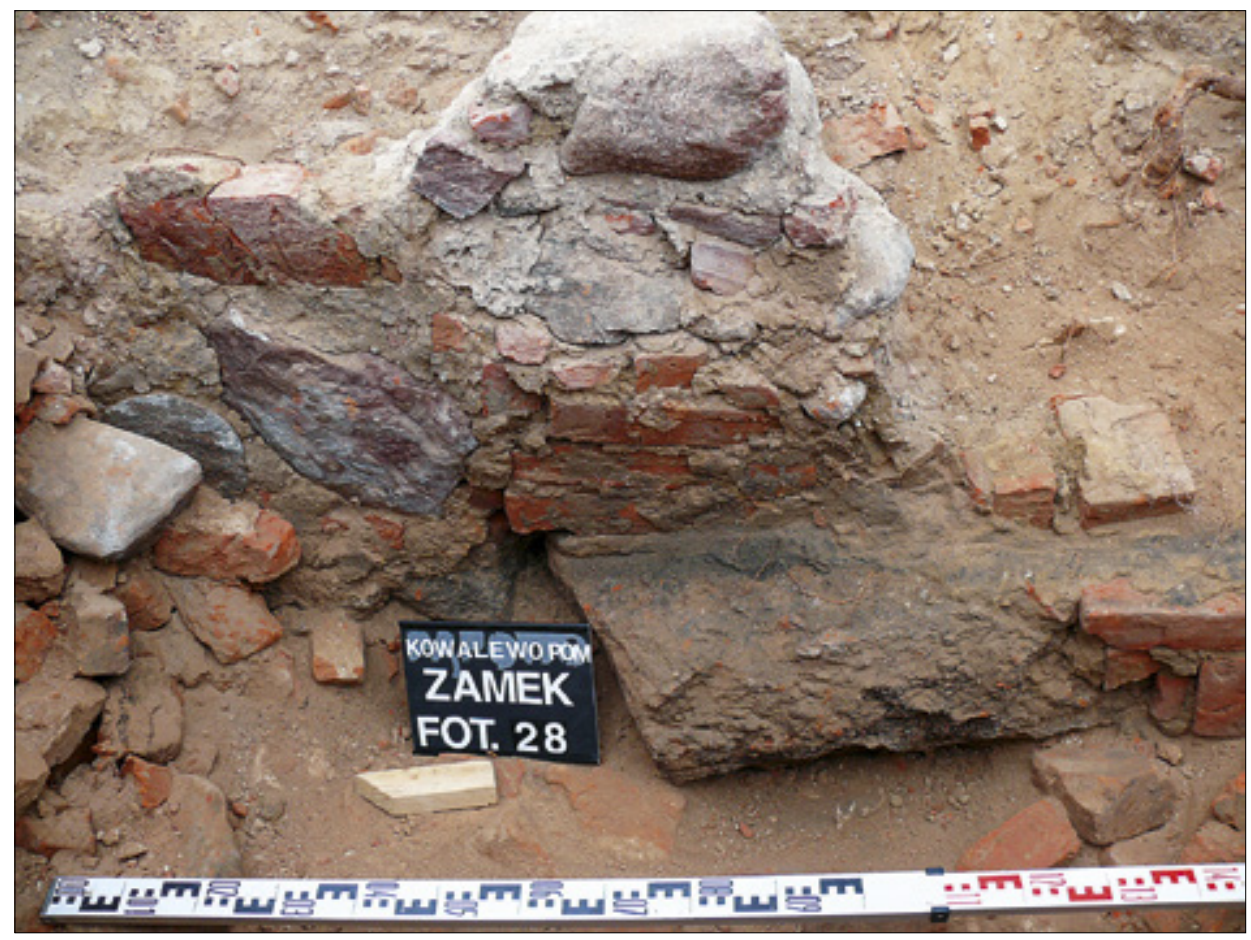

Il. 6. Kowalewo PomorskiE, wykop nr 5, relikt ściany działowej skrzydła południowego. Fot. B. Wasik 


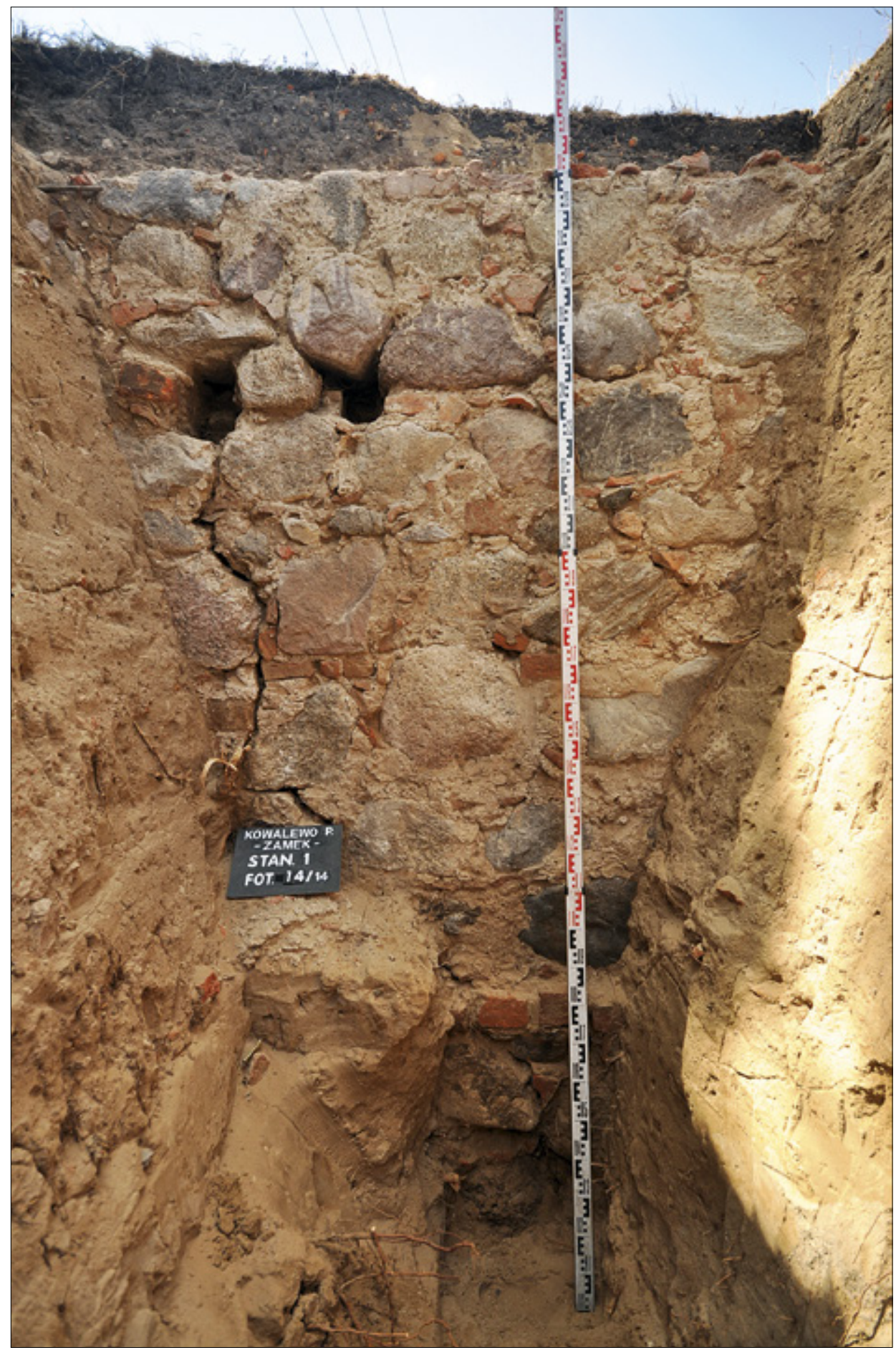

Il. 7. Kowalewo Pomorskie, wykop nr 9, lico muru parchamu. Fot. B. Wasik 
Bogusz Wasik

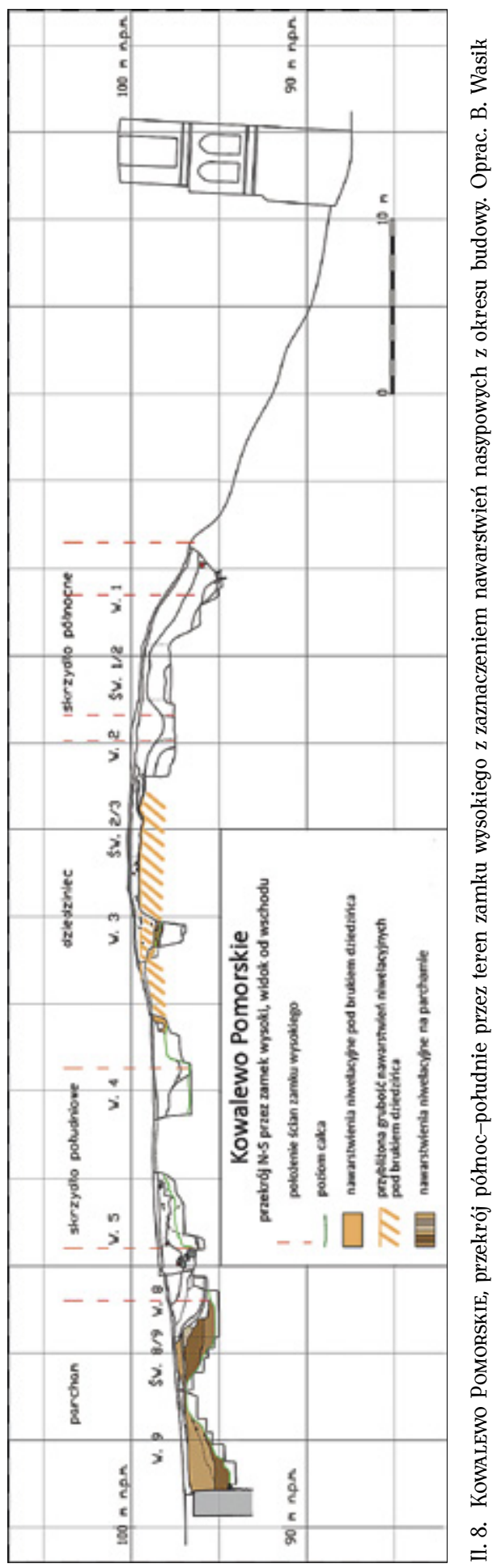

[278] 


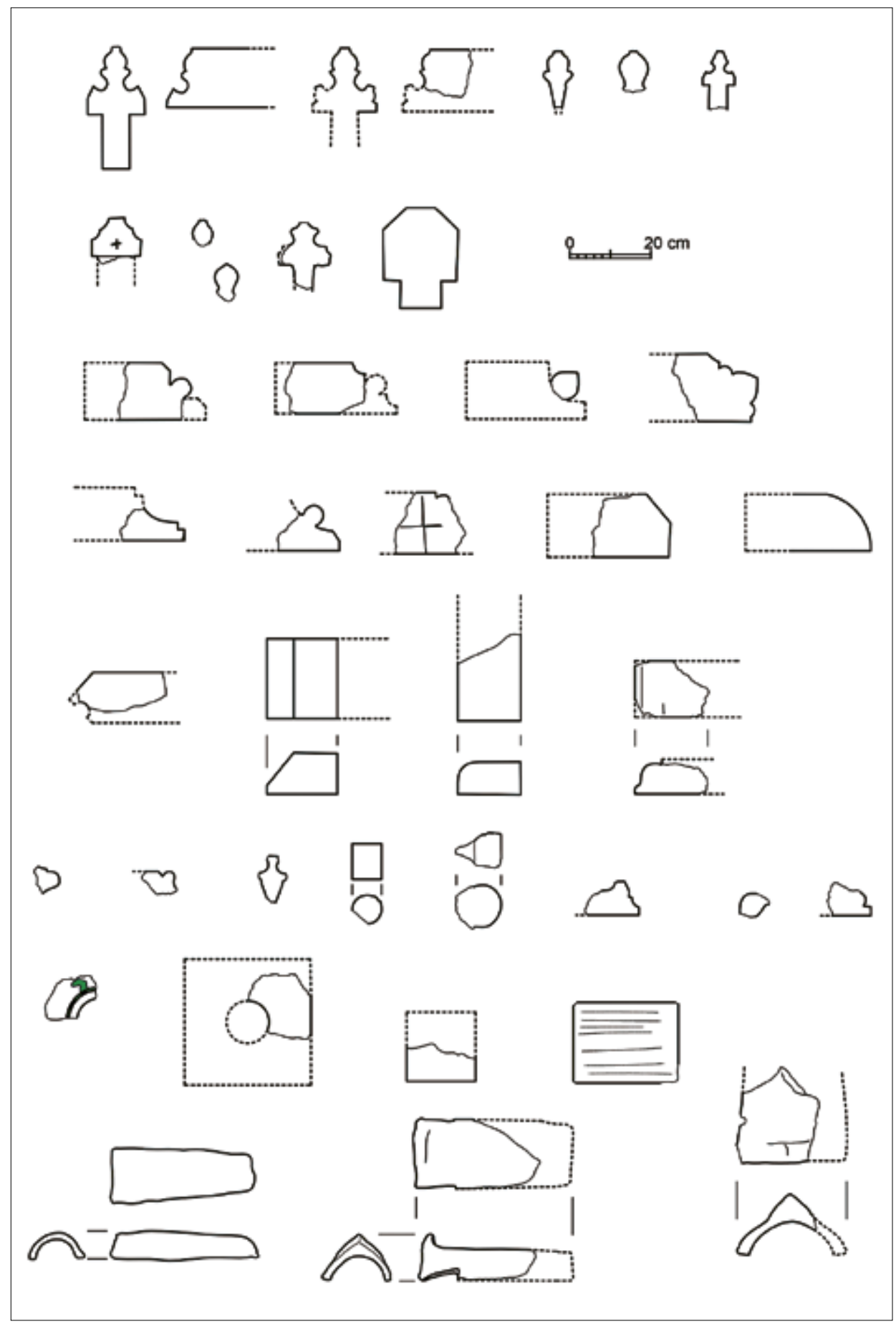

Il. 9. Kowalewo PomorskiE, kształtki i cegły specjalne wydobyte podczas badań archeologicznych. Oprac. B. Wasik 

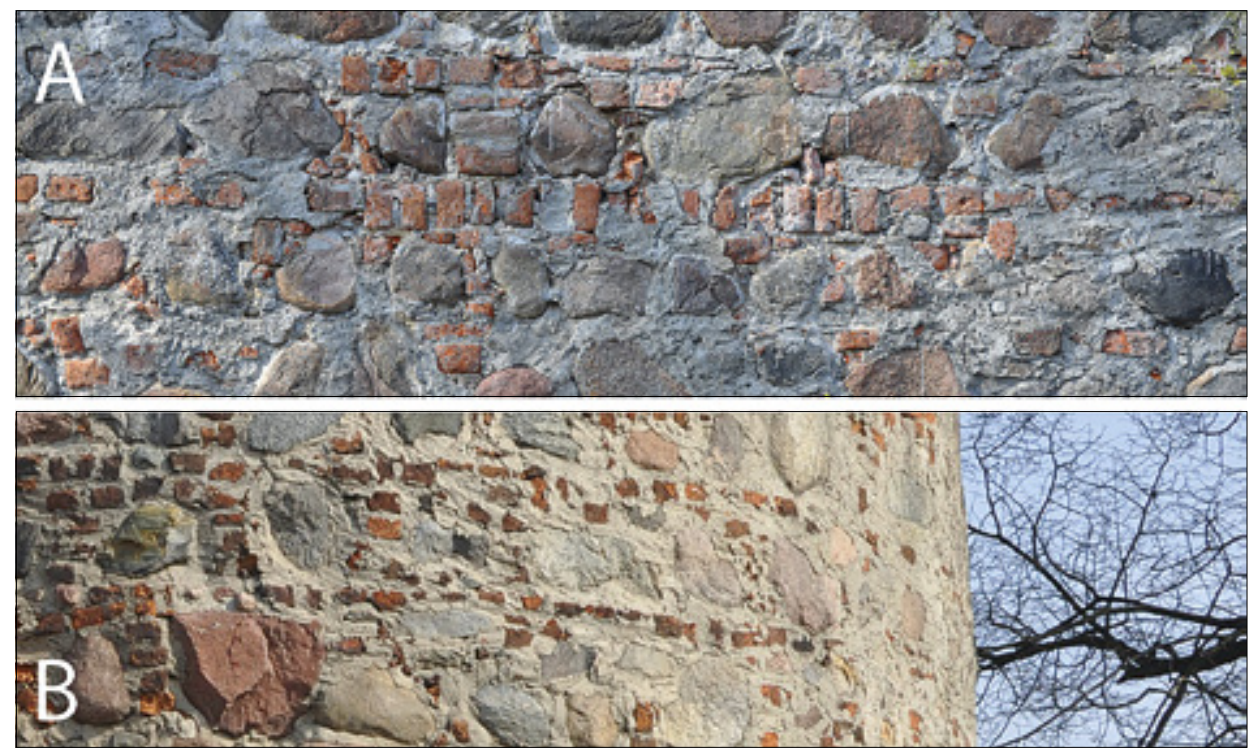

Il. 10. Kowalewo PomorskiE, kamienno-ceglany wątek murów: A - przedzamcza południowego, B - wieży w narożniku murów miejskich. Fot. B. Wasik 